\title{
The Antecedent of Customer Satisfaction and Its Impact on Customer Retention in Tourism as Hospitality Industry
}

\author{
Andala Rama Putra Barusman \\ Evelin Putri Rulian \\ Susanto \\ Bandar Lampung University \\ Bandar Lampung, Indonesia
}

\begin{abstract}
Taking a case study of tourism as hospitality industry in Lampung Province in Indonesia, we analyze the antecedent of customer satisfaction and its impact on customer retention. Using Structural Equation Model (SEM), we find that customer relationship management has a significant impact on service quality, customer satisfaction and customer retention. Moreover, the impact of service quality on customer satisfaction and the one of customer satisfaction on customer retention are aslo significant. Relying on the findings, we recommend some strategies for the government of Lampung Province, e.g. training local people to behave more friendly in welcoming domestic or international tourists, fixing all lodging facilities, creating more souvenirs with Lampung's ornaments and developing management system adopting global changes in technology, communication and trend.
\end{abstract}

Keywords: Customer Relationship Management, Service Quality, Customer Satisfaction, Customer Retention, Tourism, Hospitality Industry.

\section{Introduction}

Tourism as hospitality industry is related to accommodation, food and beverages, and all interrelated services which are intended to provide the visitors all their needs, including lodging facilities and services of a certain product in the industry. This industry is one of the sectors that supports the economy of Indonesia and its provinces. One of the Indonesia Provinces which build its tourism industry is Lampung. The province has tried to boost its tourism industry by organizing tourism events, such as Tanjung Setia Festival , Krakatoa Festival and Way Kambas Festival . Recently, the province has been popular for snorkeling and diving. Both domestic and international tourists from various diving communities have been visiting tourism areas in Lampung such as Pahawang island, Krui beach, Kiluan gulf, Ringgung beach, Kelagian island, Balak island, and Mahitam island.

By the end of the year 2016, in Lampung, tourist visiting has increased to $31.78 \%$ and new hotels have been built up to $1.78 \%$. Unfortunately, the growing number of tourists and hotels is not followed by the growing number of tourist expenditure and their length of stay, which is only US\$ 77 per day and 1,74 day per visit respectively. Therefore, the government of Lampung needs to enhance tourist expenditure and stay during the tourists' visit by, for example, increasing and maintaining their satisfaction.

By taking a case study of tourism industry in Lampung Province in Indonesia, we analyze the antecedent of customer satisfaction and its impact on customer retention. In the analysis, we study both the direct and indirect impacts and overall influence of variables. We also use a structural equation model for confirmatory factor analysis on the 
relationships between the latent and measured variables which are indicators of common factors.

\section{LITERATURE REVIEW}

\section{A. Customer Retention}

Customer retention is defined as customer's commitment towards a company and its offerings for a specific period of time through their repeat purchases and tendency in spreading positive word of mouth among their social circle [1,2]. In order to produce customer retention, the company must keep its customers by providing a great customer experience [3]. As in [4], customer retention can lead significant benefits to companies, i.e. reducing operating cost and increasing revenue by referrals. Thus, companies put customer retention as primary task because the cost of acquiring a new customer is greater than the cost of maintaining a relationship with a current customer [5].

\section{B. Factors Influencing Customer Retention}

Customer retention can be influenced by customer satisfaction [6,7], service quality [8,9] and customer relationship management [10]. Customer satisfaction is defined as the result of a cognitive and affective evaluation, where the standard expectation is compared to the actual perceived performance with disconfirmation paradigm [3,11]. In the comparison, when the performance exceeds the expectation, the result of evaluation will reach satisfaction (positively disconfirming). Conformity expectations and willingness to re-purchase and to recommend can be the attributes of custumer satisfaction [12].

Service quality can be a major factor that causes satisfaction and customer retention [13]. It is connected to customer perceptions and customer expectations and has five dimensions, i.e. tangible, reliability, responsiveness, assurance and empathy [14]. These dimensions are interrelated as in [15] showing that in tourism service quality, when many costumers were able to pay more for travel services, fewer were willing to do so.

In order to maintain the relationship with the customer for a long time, many companies are investing in customer relationship management. It is a combination of people, process, technology and communication that seeks to understand a company's customers [16]. Tourism industry can take the benefits from this management as a strategy in increasing tourist visits [17].

\section{METHODS}

The population were domestic and foreign tourists in Lampung Province. Since the population is dynamic and its nature is diverse (heterogeneous), the population is categorized as infinite. Fig. 1 shows Structural Equation Modeling (SEM) formed from latent variables (i.e. endogenous and exogenous) used in this study. Service quality, customer satisfaction and customer retention act as endogenous variables and customer relationship management as exogenous one. 


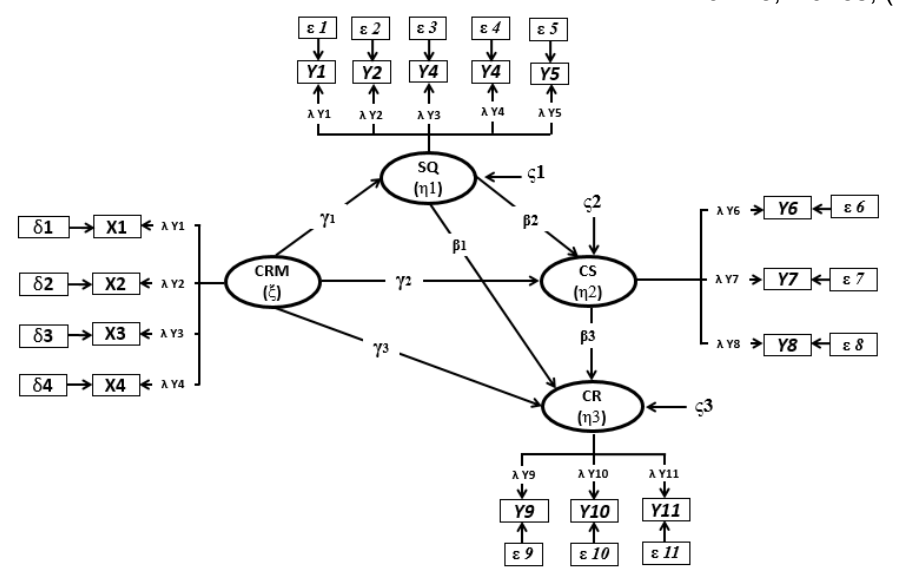

Fig. 1. Structural Equation Modeling (SEM). SQ: Service Quality; CS: Customer Satisfaction; CR: Customer Retention; CRM: Customer Relationship Management; h: latent variable Y (Endogenous variable); $\mathrm{x}$ : latent variable $\mathrm{X}$ (Exogenous variable); g: the influence of exogenous variables on endogenous variables; $\beta$ : The influence of endogenous variables on endogenous variables.

Equations (1-3) show SEM 1, 2 and 3 respectively.

$$
\begin{gathered}
\eta_{1}=\gamma_{1} \xi+\zeta_{1} \\
\eta_{2}=\gamma_{2} \xi+\beta_{2} \eta_{1}+\zeta_{2} \\
\eta_{3}=\gamma_{3} \xi+\beta_{1} \eta_{1}+\beta_{3} \eta_{2}+\zeta_{3}
\end{gathered}
$$

\section{RESULTS AND DISCUSSION}

Table 1 shows that all construct estimates of latent variables are valid and reliable because their values of Standardized Loading Factor (SLF) $>0.50$, Construct Reliability $(\mathrm{CR})>0.70$ and Variance Extracted $(\mathrm{VE})>0.50$. Therefore, the validity and reliability of the structural equation models are significant.

TABLE 1. VALIDITY AND RELIABILITY TEST OF STRUCTURAL EQUATIONS

\begin{tabular}{|l|l|l|l|l|l|}
\hline Variables & $*$ SLF $\geq \mathbf{0 . 5}$ & Error & $* \mathbf{C R} \geq \mathbf{0 . 7}$ & $* \mathbf{V E} \geq \mathbf{0 . 5}$ & Conclusion \\
\hline $\begin{array}{l}\text { Customer Relationship } \\
\text { Management (CRM) }\end{array}$ & & 0.87 & 0.64 & Reliable \\
\hline $\mathrm{X}_{1}$ (People) & 0.51 & 0.49 & & & Valid \\
\hline $\mathrm{X}_{2}$ (Process) & 0.65 & 0.35 & & & Valid \\
\hline $\begin{array}{l}\mathrm{X}_{3} \\
\text { (Technology) }\end{array}$ & 0.75 & 0.25 & & & Valid \\
\hline $\begin{array}{l}\mathrm{X}_{4} \\
\text { (Communication) }\end{array}$ & 0.92 & 0.08 & & & Valid \\
\hline Service Quality (SQ) & & 0.93 & 0.73 & Reliable \\
\hline $\mathrm{Y}_{1}$ (Tangibles) & 0.81 & 0.19 & & & Valid \\
\hline $\mathrm{Y}_{2}$ (Reliability) & 0.80 & 0.20 & & & Valid \\
\hline $\begin{array}{l}\mathrm{Y}_{3} \\
\text { (Responsiveness) }\end{array}$ & 0.69 & 0.31 & & & Valid \\
\hline $\mathrm{Y}_{4}$ (Assurance) & 0.81 & 0.19 & & & Valid \\
\hline$Y_{5}$ (Empathy) & 0.77 & 0.23 & & & Valid \\
\hline Customer Satisfaction (CS) & & 0.95 & 0.85 & Reliable \\
\hline $\begin{array}{l}\mathrm{Y}_{6} \text { (Conformity } \\
\text { Expectations) }\end{array}$ & 0.85 & 0.15 & & & Valid \\
\hline $\begin{array}{l}\mathrm{Y}_{7} \text { (Willingness } \\
\text { to Re-purchase) }\end{array}$ & 0.82 & 0.18 & & & Valid \\
\hline $\begin{array}{l}Y_{8} \text { (Willingness } \\
\text { to Recommend) }\end{array}$ & 0.94 & 0.06 & & & Valid \\
\hline
\end{tabular}




\begin{tabular}{|l|l|l|l|l|l|}
\hline \multicolumn{3}{|l|}{ Customer Retention (CR) } & 0,85 & 0,65 & Reliable \\
\hline $\begin{array}{l}\text { Y9 (Word of } \\
\text { Mouth) }\end{array}$ & 0.71 & 0.29 & & & Valid \\
\hline$Y_{10}$ (Retention) & 0.77 & 0.23 & & & Valid \\
\hline $\begin{array}{l}Y_{11} \text { (Customer } \\
\text { Loyalty) }\end{array}$ & 0.68 & 0.32 & & & Valid \\
\hline
\end{tabular}

* $\mathrm{SLF}=$ Standardized Loading Factor; $\mathrm{CR}=$ Construct Reliability; VE=Variance Extracted.

In details, Customer Relationship Management (CRM) variable consists of four indicators, i.e. X1 (people), X2 (process), X3 (technology), and X4 (communication). In CRM, X4 has the biggest influence (SLF $=0.92$ ), and X1 has the smallest influence (SLF $=0.51$ ). Service Quality (SQ) variable consists of five indicators, i.e. Y1 (tangibles), Y2 (reliability), Y3 (responsiveness), Y4 (assurance) and Y5 (empathy). In SQ, Y1 has the biggest influence $(\mathrm{SLF}=0.82)$, and $\mathrm{Y} 3$ has the smallest influence $(\mathrm{SLF}=0,69)$.

Customer Satisfaction (CS) variable consists of three indicators, i.e. Y6 (conformity expectations), Y7 (willingness to re-purchase) and Y8 (willingness to recommend). In CS, $\mathrm{Y} 8$ has the biggest influence (SLF $=0,94)$, and $\mathrm{Y} 7$ has the smallest influence (SLF $=$ 0,82). Customer Retention (CR) variable consists of three indicators, i.e. Y9 (word of mouth), Y10 (retention), Y11 (customer loyalty). In CR, Y10 has the biggest influence $(\mathrm{SLF}=0,77)$, and Y11 has the smallest influence $(\mathrm{SLF}=0,68)$.

To construct the exogenous latent variables in CRM, X1 is measured by variables: X11 (hospitality) and X12 (nice welcoming); X2 by variables: X21 (easy to get souvenirs) and X22 (easy to get transportation); X3 by variables: X31 (friendly website), X32 (ticketing via technology) and X33 (interest promotion); and X4 by variables: X41 (advertising), X42 (information from local people), and X43 (correct information). Fig. 2 shows the result of confimatory factor analysis ( 2 nd order) in CRM.

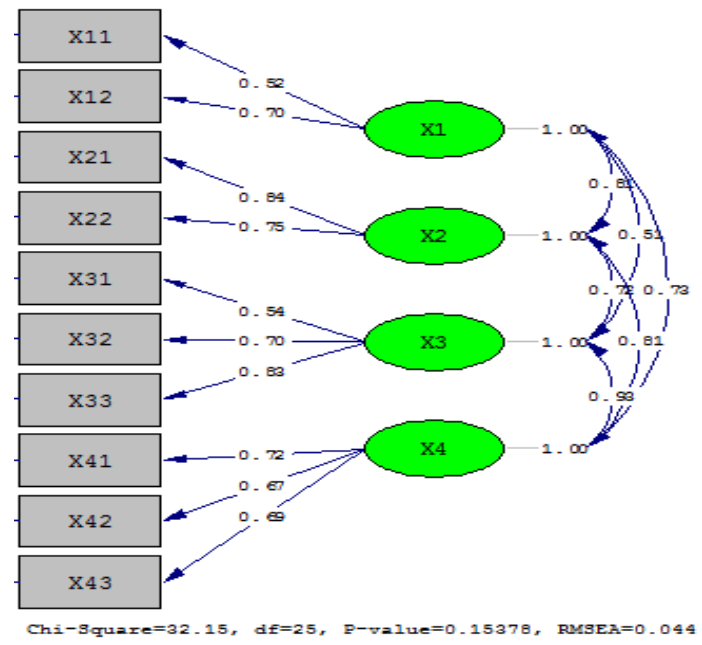

Fig. 2. Confimatory Factor Analysis (2nd order) of the exogenous latent variables in CRM

In constructing the endogenous latent variables in $\mathrm{SQ}, \mathrm{Y} 1$ is measured by variables: Y11 (nice tourist attractions), Y12 (comfortable lodging); Y2 by variables: Y21 (good service for tourists) and Y22 (good service for lodging); Y3 by variables: Y31 (good response for tourists' attraction), Y32 (good response at lodging); Y4 by variables: Y41 (safety environment) and Y42 (nice people); Y5 by variables: Y51 (knowing the tourists' attraction) and Y52 (knowing the the torurists' lodging). The result of confimatory factor analysis (2nd order) in SQ can be seen in Fig. 3. 


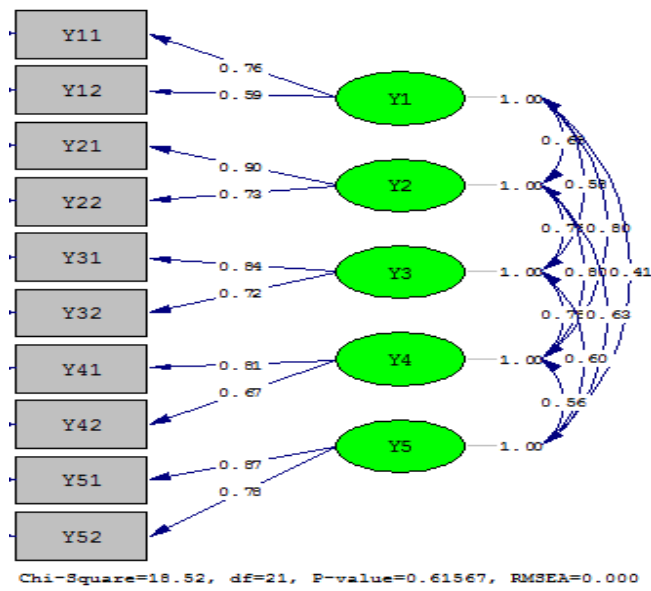

Fig. 3. Confimatory Factor Analysis (2nd order) of the endogenous latent variables in SQ.

For the endogenous latent variables in CS, Y6 is measured by variables: Y61 (completed facility), Y62 (good employee performance), Y63 (enjoying Lampung product) and Y64 (feeling satisfied and visiting again); Y7 by variables: Y71 (excellent souvenirs), Y72 (recommending souvenirs), Y73 (suggesting souvenir boutiqe); Y8 by variables: Y81 (suggestions for tourists' attraction), Y82 (suggestions for lodging) and Y83 (recommending destination for vacation). Fig. 4 shows the result of confimatory factor analysis (2nd order) in CS.

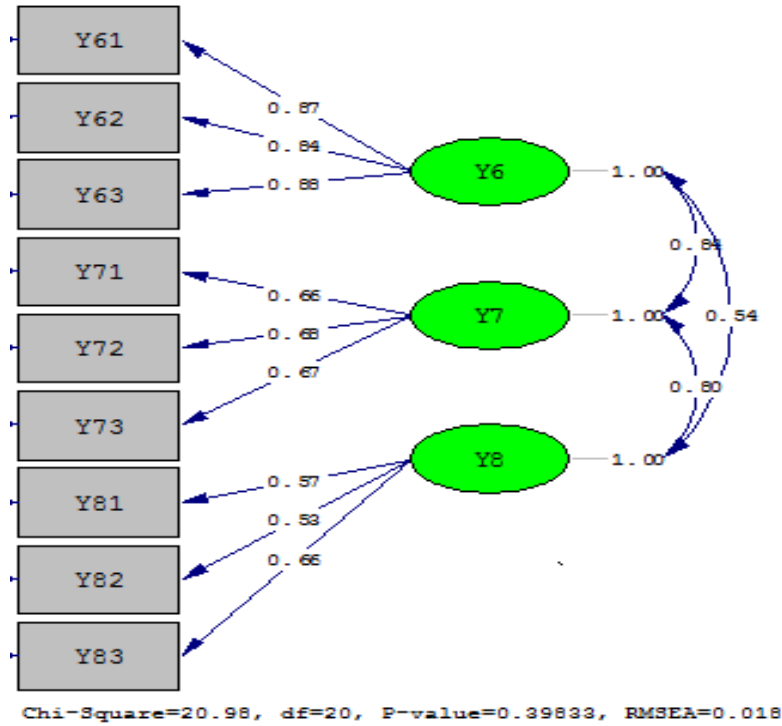

Fig. 4. Confimatory Factor Analysis (2nd order) of the endogenous latent variables in CS.

To construct the endogenous latent variables in CR, Y9 is measured by variables: Y91 (excellent hospitality), Y92 (good tourist experience) and Y93 (use lodging facility); Y10 by variables: Y101 (use lodging service), Y102 (use tourists' attraction facility), Y103 (use tourists attraction service), Y104 (satisfied in visiting Lampung); Y11 by variables: Y111 (buying some souvenirs), Y112 (quality in vacation experience) and Y113 (satisfied in vacation value). The result of confimatory factor analysis (2nd order) in CR can be seen in Fig. 5. 


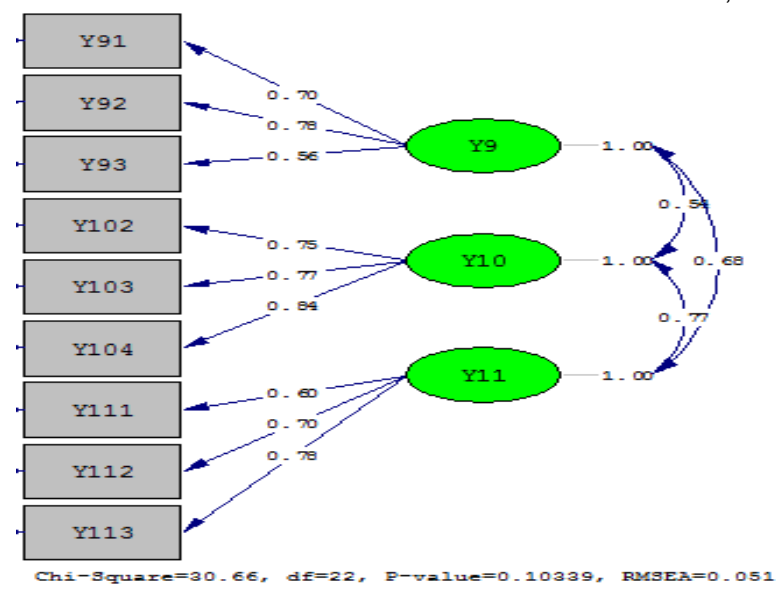

Fig. 5. Confimatory Factor Analysis (2nd order) of the endogenous latent variables in CS.

From the validity and reliability tests, the exogenous latent variables in CRM, and the endogenous latent variables in SQ, CS and CR construct valid and reliable relationship because the values of its SLF is $\geq 0.5$, its construct reliability is $\geq 0,7$ and its variance extracted is $\geq 0,5$. It is observed that only Y64 and Y101 variables are invalid and reduced.

In structural equation model, we analyse the feasibility of measurement model resulting in the previous Confirmatory Factor Analysis (2nd order). See Fig. 6 for the estimation model of structural equation with coefficient value and Fig. 7 with t-value.

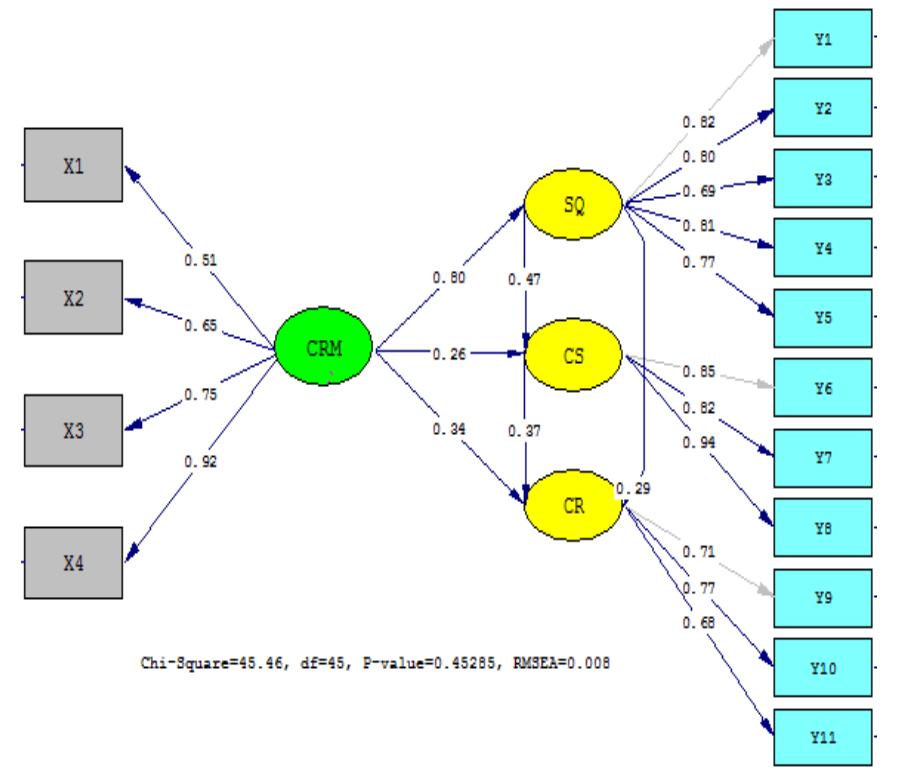

Fig. 6. Estimation of Structural Model with Coefficient Value. 


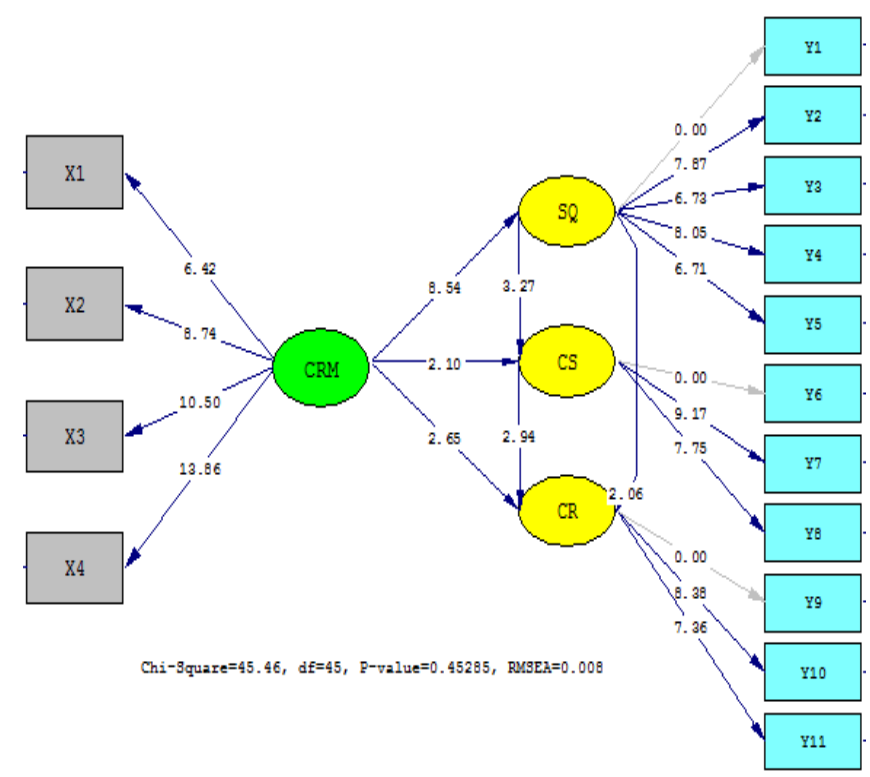

Fig. 7. Estimation of Structural Model with t-value.

The analysis in the estimation of structural models shown in Fig. 6 and Fig. 7, results in the following structural equations.

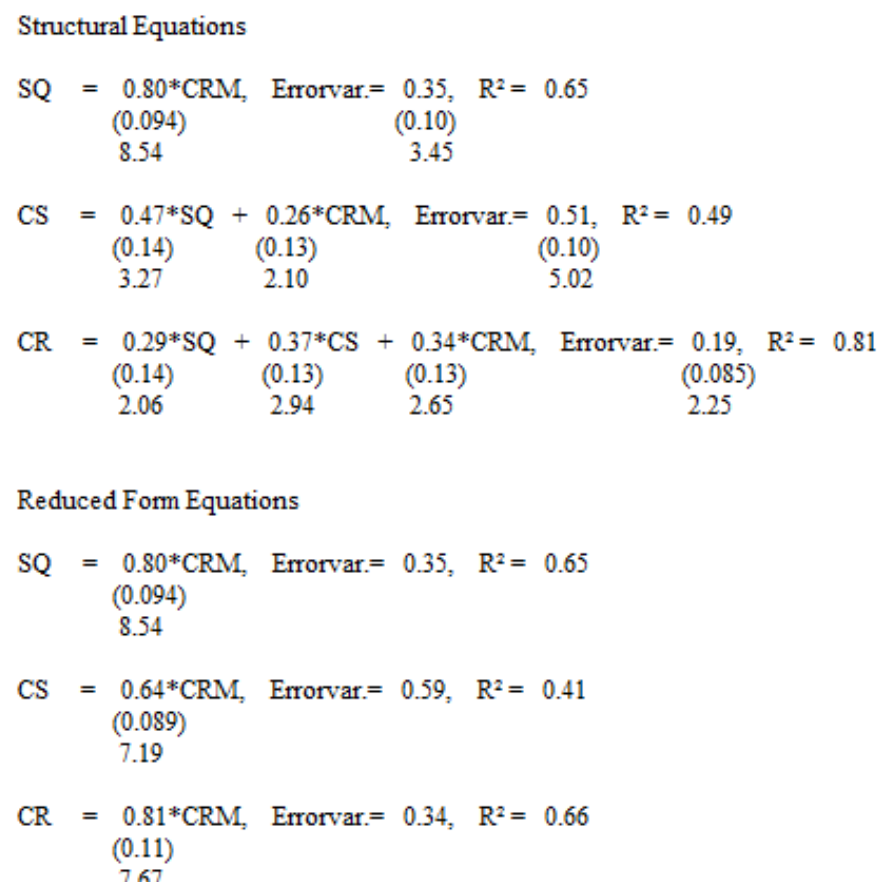

Moreover, direct, indirect and total effects of each variable can be observed in Table 2. It shows the existence of indirect effect in order to determine the effect of an exogenous variable on the endogenous variable which is dependent through endogen entervening variable. The result of indirect effect has been accordance with the desired structural model. As an example, CRM has direct and positive influence on SQ, on CS through SQ, and on CR through CS. 
TABLE 2. DIRECT, INDIRECT AND TOTAL EFFECTS OF VARIABLES

\begin{tabular}{|l|l|l|l|l|l|}
\hline \multirow{2}{*}{ Hypothesis } & \multicolumn{2}{|l|}{ Direct Effect } & \multicolumn{2}{l|}{ Indirect Effect } & $\begin{array}{l}\text { Total } \\
\text { Effect }\end{array}$ \\
\cline { 2 - 6 } & $\gamma$ & $\boldsymbol{\beta}$ & $\boldsymbol{\eta} \mathbf{I}$ & $\boldsymbol{\eta 2}$ & \\
\hline Effect of CRM to SQ & 0.80 & & & & 0.80 \\
\hline Effect of CRM to CS & 0.26 & & 0.38 & & 0.64 \\
\hline Effect of CRM to CR & 0.34 & & & 0.47 & 0.81 \\
\hline Effect of SQ to CR & & 0.29 & & & 0.29 \\
\hline Effect of SQ to CS & & 0.47 & & & 0.47 \\
\hline Effect of CS to CR & & 0.37 & & & 0.37 \\
\hline
\end{tabular}

\section{CONCLUSION}

Understanding the behavior of the customers especially for their satisfaction provides insights for strategies to attract more custumers and create custumer retention. We have analysed the antecedent of customer satisfaction and its impact on customer retention in tourism industry in Lampung, Indonesia. We find that customer relationship management has a significant impact on service quality, customer satisfaction and customer retention. Moreover, the impact of service quality on customer satisfaction and the one of customer satisfaction on customer retention are aslo significant.

Relying on the findings, we recommend some strategies related to local people hospitality, service responsiveness, custumer interest and custumer loyalty. The government of Lampung Province could, e.g. train local people to behave more friendly in welcoming domestic or international tourists, fix all lodging facilities, create more souvenirs with Lampung's ornaments and develop management system adopting global changes in technology, communication and trend.

\section{Acknowledgments}

We gratefully acknowledge the supports from Bandar Lampung University. We appreciate the comments from our colleages and students for the earlier draft of the paper. We also thank the reviewers and appreciate their comments.

\section{References}

[1] D.J.F. Jeng and T. Bailey, "Assessing Customer Retention Strategies in Mobile Telecommunications: Hybrid MCDM Approac," Management Decision, vol. 50 no. 9, pp. 15701595, 2012.

[2] H. Han, K.J. Back and B. Barrett, "Influencing factors on restaurant customers' revisit intention: The roles of emotions and switching barriers," International Journal of Hospitality Management, vol. 28 no. 4, pp. 563-572, 2009.

[3] P. Kotler and K.L. Keller, Marketing Management, 15th ed. New York: Pearson Education, 2016.

[4] O.C. Ferrell and M.D. Hartline, Marketing Strategy, 5th ed. Boston, MA: Cengage Learning, 2010.

[5] R. Singh and I.A. Khan, "An Approach to Increase Customer Retention and Loyalty in B2C World," International Journal of Scientific and Research Publications, vol. 2 no. 6, pp. 1-5, 2012.

[6] K. Seiders, G.B. Voss, D. Grewal and A.L. Godfrey, "Do Satisfied Customers Buy More? Examining Moderating 
Influences in A Retailing Context," Journal of Marketing, vol. 69, pp. 26-43, 2005.

[7] R.W. Yee, A.C. Yeung and T.C.E. Cheng, "An Empirical Study of Employee Loyalty, Service Quality and Firm Performance in the Service Industry," International Journal of Production Economics, vol. 124 no. 1, pp. 109$120,2010$.

[8] M.K. Kim, M.C. Park and D.H. Jeong, "The Effects of Customer Satisfaction and Switching Barrier on Customer Loyalty in Korean Mobile Telecommunication Services," Telecommunications Policy, vol. 28 no. 2, pp. 145-159, 2004.

[9] S.A. Sharmeela-Banu, K. Gengeswari and P. Padmashantini, "Customer Retention Practices among the Major Retailers in Malaysia," International Journal of Academic Research in Business and Social Sciences, vol. 2 no. 6, pp. 157-166, 2012.

[10] K. Tawinunt, T. Phimonsathien and F. Wanno, "Service Quality and Customer Relationship Management Affecting Customer Retention of Long-Stay Travelers in the Thai Tourism Industry: A SEM approach," International Journal of Arts \& Sciences, vol. 8 no. 2, pp. 459-477, 2015.

[11] K. Weber, "The Assessment of Tourist Satisfaction Using the Expectancy Disconfirmation Theory: A study of the German travel market in Australia," Pacific Tourism Review, vol. 1, pp. 35-45, 1997.

[12] F. Tjiptono, Strategi Pemasaran (Marketing Strategy), 2nd ed. Yogyakarta: Andi, 2004.

[13] B.B. Parida and A.K. Baksi, "Customer Retention and Profitability: CRM Environment," SCMS Journal of Indian Management, vol. 8 no. 2, pp. 66-84, 2011.

[14] V.A. Zeithaml, A. Parasuraman and L.L. Berry, Delivering Quality Services. New York: The Free Press, 1990.

[15] A.Dean, D. Morgan, and T.E. Tan, "Service Quality and Customer's Willingness to Pay More for Travel Service," Journal of Travel and Tourism Marketing, vol. 12 no. 2/3, pp. 95-110, 2002.

[16] I.J. Chen and K. Popovich, 2003, "Understanding customer relationship management (CRM): People, process and technology," Business Process Management Journal, vol. 9 no. 5, pp. $672-688,2003$.

[17] S. Ivanovic, K. Mikinac and L. Perman, Luka, "CRM Development in Hospitality Companies for the Purpose of Increasing the Competitiveness in the Tourist Market," UTMS Journal of Economics, vol. 2 no. 1, pp. 59-68, 2011. 